\title{
Selection of reference genes for normalization of quantitative real-time PCR in cell cultures of Cyclamen persicum
}

\author{
Claudia Hoenemann ${ }^{1}$ - Annette Hohe ${ }^{1} \square$ \\ 1 Leibniz-Institute of Vegetable and Ornamental Crops, Erfurt, Germany \\ $\triangle$ Corresponding author: hohe@erfurt.igzev.de \\ Received June 17, 2010 / Accepted December 3, 2010 \\ Published online: January 15, 2011 \\ C 2011 by Pontificia Universidad Católica de Valparaíso, Chile
}

\begin{abstract}
As a prerequisite for gene expression analyses in cell cultures of the ornamental crop Cyclamen persicum basic parameters for quantitative real-time polymerase chain reaction (qRT-PCR) have been established including the selection of reference genes using the software tools 'geNorm' and 'NormFinder'. Five potential reference genes have been tested (elongation factor tu (Ef-Tu), putative ABC transporter ATPase, putative conserved oligomeric Golgi (COG) complex component, VATPase $\mathrm{G}$ subunit 1 and Histone H3-K9 methyltransferase 4 (H3-K9-HMTase 4)). 'NormFinder' as well as 'geNorm' identified Ef-Tu to be the least stable reference gene while the ranking of the most stable genes differed depending on the algorithm. According to 'NormFinder' COG complex component displayed the most stable expression whereas 'geNorm' indicated V-ATPase G subunit 1 and a putative $A B C$ transporter ATPase to be the most reliable reference genes. Hence, we concluded to use a normalization factor calculated from the four reference genes V-ATPase $G$ subunit 1 , ABC transporter ATPase, Histone H3-K9 methyltransferase 4 (H3-K9-HMTase 4) and COG complex component for normalization of qRT-PCR in cell cultures of Cyclamen persicum.
\end{abstract}

Keywords: gene expression analysis, in vitro propagation, primer design, somatic embryogenesis

\section{INTRODUCTION}

Quantitative real-time polymerase chain reaction (qRT-PCR) has become a very powerful technique to determine steady-state transcription levels of selected genes of interest (GOI) (Bustin, 2002; Ginzinger, 2002). The technique of qRT-PCR has first been documented in 1993 (Higuchi et al. 1993). Since then it has been continually improved and refined so that it serves as a routine tool in molecular biology today with a wide range of applications (Bustin, 2002). Parallel to the technical improvements and the drastically rising applications, requirements for methodological standardization and quality control have evolved (Bustin et al. 2009). The accuracy of qRT-PCR depends on several specific features of this novel technique, but it also suffers from the problems inherent in reverse transcription (RT) and PCR in general (Pfaffl, 2004). Two major concerns in this context are primer design and concentration as well as the selection of an appropriate normalization strategy.

Assays using SYBR Green may suffer from unspecific amplification (since SYBR Green is staining any double stranded DNA) and from the formation of primer-dimers, i.e. primer molecules that have hybridized to each other resulting in amplification of primer sequences instead of the target transcript (Morrison et al. 1998). To differentiate primer-dimers from the specific amplicon a melting curve analysis should be performed. After amplification the temperature is continuously increased resulting in denaturing of the DNA double strands which releases the SYBR Green dye so that the fluorescence decreases. The melting temperature is highly specific for different PCR products. Pure and homogeneous products produce a single, sharply defined melting curve with a narrow peak, while - in contrast - primer-dimers melt at relatively low temperatures and generate broader peaks (Ririe et al. 1997). 
With regard to calculation of quantities, relative quantification evolved as the method of choice for most applications, i.e. to compare the transcript abundance (commonly referred to as the 'gene expression level') of the gene of interest with that of reference genes whose expression levels do not change under various experimental conditions. Many studies make use of potential constitutively expressed control genes without proper validation of their stability of expression (Vandesompele et al. 2002). However, the use of reference genes without prior verification of the stability of their transcript abundance might generate incorrect results (Vandesompele et al. 2002; Brunner et al. 2004; Pfaffl et al. 2004).

In this study, the basic steps (RNA isolation, cDNA synthesis, primer design and concentration determination) of establishing qRT-PCR in Cyclamen persicum are presented including the evaluation of five potential reference genes. C. persicum has evolved as a model plant for studying the effect of in vitro culture procedures on the process of somatic embryogenesis on the molecular level (Rensing et al. 2005; Winkelmann et al. 2006; Lyngved et al. 2008; Bian et al. 2010). For the horticultural industry vegetative propagation via somatic embryogenesis would be highly desirable in this crop. However, the protocol (Schwenkel and Winkelmann, 1998) is not reproducible and robust enough for use in routine propagation (Seyring and Hohe, 2005). Gene expression studies have been initiated in order to better understand the underlying physiological processes (Rensing et al. 2005; Hoenemann et al. 2010).

\section{MATERIALS AND METHODS}

\section{Plant material}

Embryogenic cell cultures of Cyclamen persicum have been established and maintained according to Schwenkel and Winkelmann (1998), Winkelmann et al. (1998) and Hoenemann et al. (2010). Five different tissues (specified in Table 1) have been selected for the current analysis.

\section{Isolation of RNA and cDNA synthesis}

RNA was isolated using the RNeasy Plant Mini Kit (Qiagen) according to the manufacturer's instructions and modifications as described by Dhanaraj et al. (2004). The protocol was conducted using the original buffers and modified 'RLT' lysis buffer (Dhanaraj et al. 2004) which were supplemented with $0.5 \%(\mathrm{v} / \mathrm{v})$ beta-mercaptoethanol, $1.25 \%$ (w/v) polyvenylpyrrolidone-3000 (PVP 3000 ) and $2 \%(\mathrm{w} / \mathrm{v})$ sodiumsarcosyl. For eliminating genomic DNA contamination the on-column DNase digestion was performed according to the manufacturer's instructions. RNA was quantified using the Qubit fluorimeter (Invitrogen). First strand cDNA was synthesised from up to $1 \mu \mathrm{g}$ of total RNA using the QuantiTect Reverse transcription Kit (Qiagen).

\section{Selection of potential reference genes}

Five putative reference genes (elongation factor thermo unstable (Ef-Tu) (CYC16T7_A05), putative ABC transporter ATPase (CYC09T7_H06), V-ATPase G subunit 1 (CYC21T7_D01), conserved

Table 1. Plant and in vitro culture material of Cyclamen persicum.

\begin{tabular}{|c|c|c|c|}
\hline Cell Line & Culture & Developmental Stage & Embryogeneity \\
\hline $\begin{array}{l}\text { F1 out of 3-2- } \\
0503\end{array}$ & zygotic embryo & $84-85$ days after pollination & yes \\
\hline $3-43-0503$ & callus & $\begin{array}{c}0 \mathrm{~h} \text { before transfer to standard media } \\
\text { without hormones }\end{array}$ & no longer \\
\hline $3-76-0503$ & suspension & $\begin{array}{c}4 \mathrm{hrs} \text { after transfer to } U \text { media without } \\
\text { hormones }\end{array}$ & $\begin{array}{l}\text { yes, torpedo- } \\
\text { shaped s.e. }\end{array}$ \\
\hline $3-76-0503$ & $\begin{array}{l}\text { somatic embryo out of } \\
\text { suspension }\end{array}$ & $\begin{array}{l}\text { 20-22 days - torpedo-shaped somatic } \\
\text { embryo }\end{array}$ & $\begin{array}{l}\text { yes, torpedo- } \\
\text { shaped s.e. }\end{array}$ \\
\hline $3738-12 G$ & callus & $\begin{array}{l}0 \mathrm{~h} \text { before transfer to standard media } \\
\text { without hormones }\end{array}$ & never \\
\hline
\end{tabular}


oligomeric Golgi (COG) complex component (CYC34T7_F01) and H3-K9 methyltransferase 4(H3-K9HMTase 4) (CYCO2F2_C10); sequences available from http://www.cyclamen-est.de) have been selected on the basis of preceding comprehensive microarray data including a wide range of tissues under various conditions (Hoenemann et al. 2010). Genes which are known to have a housekeeping function and which displayed stable transcript abundances in all microarray experiments have been selected for analysis (Table 2).

\section{Primer design and primer concentration determination}

PCR primer sequences were designed using Primer3 (Rozen and Skaletsky, 2000, available from the internet: http://biotools.umassmed.edu/bioapps/primer3 www.cgi). The optimal primer concentrations were analyzed in ranges of 100 to $500 \mathrm{nM}$ of each primer. Primer sequences and conditions for amplification are given in Table 2.

\section{qRT-PCR methodology}

The transcript abundances of five selected putative reference genes were quantitatively measured by qRT-PCR in five different tissues each. PCR amplification was performed in a Stratagene Mx3000P qRT-PCR System (Stratagene, La Jolla, CA, USA) using ABsolute QPCR SYBR Green ROX Mix (ABgene, Epsom, Surrey KT19 9AP, UK). PCR reactions were carried out in a total volume of $25 \mu \mathrm{l}$, consisting of $1 \mathrm{ng}$ cDNA, 100 to $500 \mathrm{nM}$ forward primer, 100 to $500 \mathrm{nM}$ reverse primer and $12.5 \mu \mathrm{l}$ ABsolute QPCR SYBR Green ROX Mix. The qRT-PCR program consisted of an initial denaturation step at $95^{\circ} \mathrm{C}$ for $15 \mathrm{~min}, 40$ cycles of amplification with denaturation at $95^{\circ} \mathrm{C}$ for $15 \mathrm{sec}$, primer annealing for $1 \mathrm{~min}$ at $59^{\circ} \mathrm{C}$ and elongation at $72^{\circ} \mathrm{C}$ for $1 \mathrm{~min}$. The amplification steps were ensued by a melting range analysis with one cycle at $95^{\circ} \mathrm{C}$ for $1 \mathrm{~min}, 59^{\circ} \mathrm{C}$ for $1 \mathrm{~min}$ and $95^{\circ} \mathrm{C}$ for $30 \mathrm{sec}$ with continuously measured fluorescence. All experiments were performed for a set of three biological replicates in triplicate. For evaluating amplification efficiencies standard curves were calculated according to common methods (Livak and Schmittken, 2001; Pfaffl, 2004).

Table 2. Primer sequences, primer concentrations, product sizes and annealing temperatures.

\begin{tabular}{|c|c|c|c|c|c|c|}
\hline $\begin{array}{l}\text { Abbreviated } \\
\text { Gene } \\
\text { Designation }\end{array}$ & $\begin{array}{l}\text { Putative Gene } \\
\text { Product }\end{array}$ & Genbank & $\begin{array}{c}\text { Forward Primer }(F) \\
\text { Reverse Primer }(\mathrm{R}) \\
5^{\prime} \rightarrow 3^{\prime}\end{array}$ & $\begin{array}{l}\text { Product } \\
\text { Size (Bp) }\end{array}$ & $\begin{array}{l}\text { Annealing } \\
\text { Temp }\left({ }^{\circ} \mathrm{C}\right)\end{array}$ & $\begin{array}{c}\text { Primer } \\
\text { Concentration } \\
(\mathrm{Nm})\end{array}$ \\
\hline Ef-Tu & Elongation factor tu & AJ886626 & $\begin{array}{l}\text { F: TATCCAGAGGGGGATGGTT } \\
\text { R: TGCCTACCTCCCTCTTCCT }\end{array}$ & 102 & 59 & 200 \\
\hline $\begin{array}{l}\text { ABC } \\
\text { transporter } \\
\text { ATPase }\end{array}$ & $\begin{array}{l}\text { ABC transporter } \\
\text { ATPase }\end{array}$ & AJ886326 & $\begin{array}{l}\text { F:TGGCGAAACGTATTGAGAA } \\
\text { R:AGTTGCTGGGGTTAGCATTT }\end{array}$ & 98 & 59 & 100 \\
\hline $\begin{array}{l}\text { V-ATPase G } \\
\text { subunit } 1\end{array}$ & $\begin{array}{l}\text { V-ATPase G } \\
\text { subunit } 1\end{array}$ & AJ887447 & $\begin{array}{l}\text { F: AGATCGGGTGCTAATGTGA } \\
\text { R: AATCCCAGCATCGTTTTTCT }\end{array}$ & 79 & 59 & 400 \\
\hline $\begin{array}{c}\text { COG complex } \\
\text { component }\end{array}$ & $\begin{array}{l}\text { putative conserved } \\
\text { oligomeric Golgi } \\
\text { (COG) complex } \\
\text { component }\end{array}$ & AJ887962 & $\begin{array}{l}\text { F:TATCCAACGCCGACAAAATA } \\
\text { R:GGAATGCTTCGATTTTTGCT }\end{array}$ & 105 & 59 & 200 \\
\hline $\begin{array}{c}\mathrm{H} 3-\mathrm{K} 9-\mathrm{HMT} \text { ase } \\
4\end{array}$ & $\begin{array}{c}\text { Histone } \mathrm{H} 3-\mathrm{K} 9 \\
\text { methyltransferase } 4\end{array}$ & AJ885940 & $\begin{array}{l}\text { F: GGTGTGAGATCTTGGGATT } \\
\text { R: GTCAAGCCCCTTCATTGTTT }\end{array}$ & 148 & 59 & 200 \\
\hline PRK & $\begin{array}{l}\text { putative receptor } \\
\text { kinase }\end{array}$ & AJ886123 & $\begin{array}{l}\text { F: GTGGTGAGAGAAGAATGGA } \\
\text { R: GCATTTTAGGCCTCTTTTCG }\end{array}$ & 107 & 59 & 400 \\
\hline
\end{tabular}




\section{Data analysis}

For each of the five reference genes (in each of the five tissues) the cycle threshold $\left(C_{t}\right)$ was determined, i.e. the number of PCR cycles after which the fluorescence from a sample crosses the threshold (automatically amplification based). These $C_{t}$ values have been transformed to relative quantities by subtraction of the lowest $C_{t}$ value, i.e. the $C_{t}$ value from the tissue with the highest transcript abundance from the $C_{t}$ values of all tissues for each transcript measured, resulting in five delta $C_{t}$ values for each transcript (according to the five different tissues). Subsequently each data point was transformed according to the formula $2^{\text {(-delta Ct) }}$ resulting in raw reference gene quantities which are the required input data for 'geNorm' (Vandesompele et al. 2002) and 'NormFinder' (Andersen et al. 2004). 'geNorm' is an application tool for Microsoft Excel (Vandesompele et al. 2002). Data was loaded to the 'geNorm' macro file (geNorm.xls, available from internet: http://medgen.ugent.be/ jvdesomp/genorm/). 'NormFinder.xla' is an Add-In for Microsoft Excel which adds the 'NormFinder' (Andersen et al. 2004) functionality directly to the Microsoft Excel software package (available from internet: http://www.mdl.dk/publicationsnormfinder.htm).

\section{RESULTS AND DISCUSSION}

\section{Primer concentration determination}

In SYBR Green-based qRT-PCR the sensitivity of the assay should be maximized in order to minimize the formation of non-specific amplification products. Therefore, it is necessary to use the lowest concentration of primers possible without compromising the efficiency. Thus, the primer concentrations that yielded the lowest $\mathrm{C}_{\mathrm{t}}$ values, i.e. resulted in the highest target amplification, were identified. For EfTu (CYC16T7_A05), COG complex component (CYC34T7_F01) and Histone H3-K9-HMTase 4 (CYC02F2_C10) the optimal primer concentration proved to be $200 \mathrm{nM}$, while $100 \mathrm{nM}$ was optimal for ABC transporter ATPase (CYC09T7_H06) and 400 nM for V-ATPase G subunit 1 (CYC21T7_D01). All primers passed efficiency evaluation calculated by standard curves. Besides, it was ensured that the primer concentrations chosen also minimized the presence of non-specific amplification products by dissociation curve analysis. Efficiencies were calculated with the Mx3000P Software (MxPro). Investigated transcripts showed high efficiency rates of 99\% (ABC transporter ATPase and V-ATPase G subunit 1) and 101\% (COG complex component and Histone H3-K9-HMTase 4) for the investigation range from 2.0 to $0.125 \mathrm{ng}$ cDNA input with high linearity for the optimal primer concentration reported.

\section{Validation of reference genes}

The average expression stability $M$ of the tested genes was calculated using the software 'geNorm' (Vandesompele et al. 2002), which is based on the "pairwise comparison strategy". The M value is defined as the average pairwise variation of a particular gene with all other reference genes within a given group of cDNA samples. The average $M$ values of the examined reference genes are plotted in Figure 1. The gene with the lowest $M$ value is considered to have the most stable expression, while that one with the highest $M$ value has the least stable expression. As shown in Figure 1a, the average expression stability value (M) of V-ATPase G subunit 1 (CYC21T7_D01) and ABC transporter ATPase (CYC09T7_H06) ranked lowest whereas that of Ef-Tu (CYC16T7_A05) turned out to be the highest. These results indicate that V-ATPase G subunit 1 (CYC21T7_Do1) and ABC transporter ATPase (CYC09T7_H06) displayed the most stable transcript abundance while that of Ef-Tu (CYC16T7_A05) was most variable.

Expression levels of ideal reference genes should not be affected by different developmental or environmental conditions. However, already numerous studies have described that also the expression level of housekeeping genes can vary considerably with experimental conditions (Jain et al. 2006; Hong et al. 2008; Cruz et al. 2009; Silveira et al. 2009). This is also supported by our data showing that the expression levels of all analyzed reference genes were not totally stable.

Consequently, normalization of gene expression with a single reference gene can trigger erroneous data and therefore would cause misinterpretation of experiment results. Thus, normalization with multiple reference genes has recently evolved as new standard in the analyses of quantitative PCR data as already reported by various studies in other biological systems (Tong et al. 2009; Artico et al. 2010; Lee et al. 2010; Maroufi et al. 2010). 
The minimum number of reference genes included in the normalization factor has been determined by calculation of the pairwaise variation of two sequential normalization factors $(\mathrm{Vn} / \mathrm{n}+1)$ containing an increasing number of genes using the 'geNorm' software (Vandesompele et al. 2002). Here, the inclusion of a fourth gene $(\mathrm{V} 3 / 4)$ resulted in the lowest pairwise variation $\mathrm{V}$ of 0.22 , while there was an increase in instability with the addition of a fifth gene (V 4/5). Although Vandesompele et al. (2002) recommended 0.15 as a cut-off value, other studies (Kuijk et al. 2007; Silveira et al. 2009) also resulted in higher pairwise variations. Therefore we suggest to calculate a normalization factor in our case using the four least variable reference genes V-ATPase G subunit 1 (CYC21T7_D01), ABC transporter ATPase (CYC09T7_H06), Histone H3-K9-HMTase 4 (CYC02F2_C10) and CŌG complex component (CYC34T7_F01).

In addition to the analysis by 'geNorm' the data were also evaluated with the 'NormFinder' algorithm (Andersen et al. 2004). While 'geNorm' selects two genes with a low intra-group variation and approximately the same non-vanishing inter-group variation, 'NormFinder' takes into account the best two genes with minimal combined intra- and intergroup expression variation for normalization factor (NF) calculations (Andersen et al. 2004). Results generated by the 'NormFinder' calculation are presented in Figure 1b. This result differed from the ranking generated by 'geNorm', which could be

a

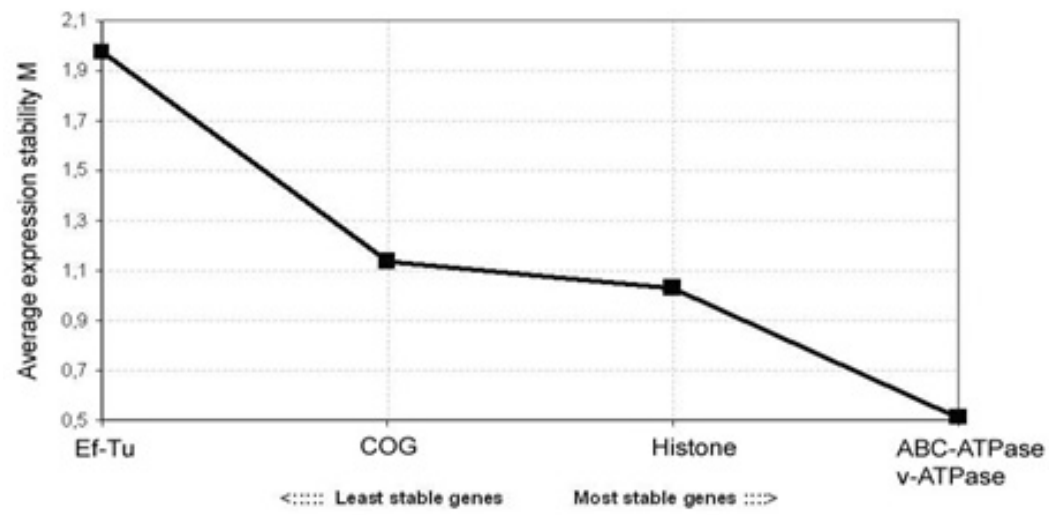

b

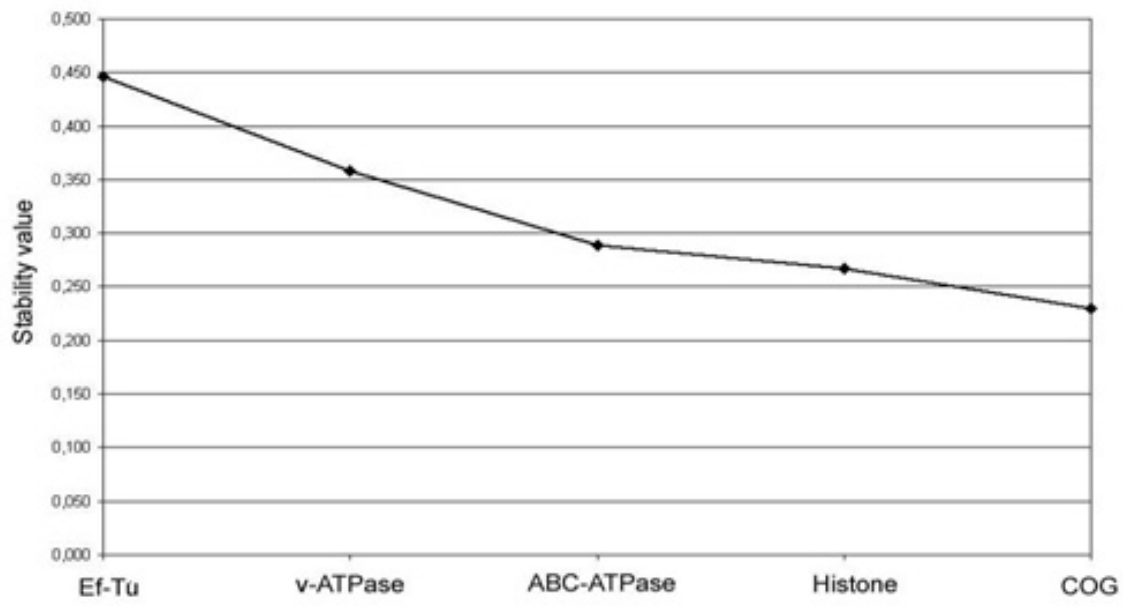

Fig. 1 Comparison of 'geNorm' and 'NormFinder' outcome: (a) 'geNorm' (Average expression stability value M of reference genes starting from the least stable gene at the left and ending with the most stable genes at the right). (b) NormFinder (Stability values for each gene starting from the least stable gene at the left and ending with the most stable gene at the right). 
expected since both software tools are based on distinct statistical algorithms. However, Ef-Tu (CYC16T7_A05) ranked poorest in both algorithms and should be avoided as internal control when doing gene expression studies in embryogenic cell cultures of $C$. persicum.

The evaluation of different algorithms for reference gene selection allows a better validation of the most reliable controls and has thus become a routine tool for selection of reference genes in a wide range of organisms in the recent years (Tong et al. 2009; Artico et al. 2010; Lee et al. 2010). If different algorithms generate differing results the decision should depend on the application. An advantage of 'geNorm' is to identify the appropriate number of reference genes while 'NormFinder' is less sensitive towards co-regulation, because it examines the stability of each single reference gene independently (Lee et al. 2010).

The four identified reference genes were used for normalization of the gene expression level of a gene of interest (putative receptor kinase (PRK), CYC04T7_G0, Table 2). Exemplarily the expression levels of this gene were compared in zygotic and somatic embryos. It was shown that the transcript abundance was 3.2-fold increased in somatic embryos compared to zygotic embryos. Receptor protein kinases play an important role in several signal transduction pathways that elicit a developmental response to exogenous input (Becraft, 2002). Thus our result might be interpreted as a hint on the special impact of this gene in the process of somatic embryogenesis that is strongly dependent on exogenous triggers (Hoenemann et al. 2010).

Hence for our studies in the experimental system of cell cultures of $C$. persicum, we concluded to use a normalization factor calculated as the geometric mean of the four reference genes $V$-ATPase $G$ subunit 1 (CYC21T7_D01), ABC transporter ATPase (CYC09T7_H06), Histone H3-K9-HMTase 4 (CYC02F2_C10) and COG complex component (CYC34T7_F01) for normalization of qRT-PCR.

\section{ACKNOWLEDGMENTS}

The authors thank Katja Krueger for excellent technical assistance and Stefan Rensing (University of Freiburg) for fruitful discussions on gene expression studies.

Financial support: The results were obtained within a project funded by the DFG to Annette Hohe (HO 2100/2-1) and Stefan A. Rensing (RE 1697/3-1).

\section{REFERENCES}

ANDERSEN, C.L.; JENSEN, J.L. and ØRNTOFT, T.F. (2004). Normalization of real-time quantitative reverse transcription-PCR data: A model-based variance estimation approach to identify genes suited for normalization, applied to bladder and colon cancer data sets. Cancer Research, vol. 64 , no. 15 , p. 52455250. [CrossRef]

ARTICO, S.; NARDELI, S.M.; BRILHANTE, O.; GROSSI-DE-SA, M.F. and ALVES-FERREIRA M. (2010). Identification and evaluation of new reference genes in Gossypium hirsutum for accurate normalization of real-time quantitative RT-PCR data. BMC Plant Biology, vol. 10, no. 49. [CrossRef]

BECRAFT, P.W. (2002). Receptor kinase signaling in plant development. Annual Review of Cell and Developmental Biology, vol. 18, p. 163-192. [CrossRef]

BIAN, F.; ZHENG, C.; QU, F.; GONG, X. and YOU, C. (2010). Proteomic analysis of somatic embryogenesis in Cyclamen persicum Mill. Plant Molecular Biology Reporter, vol. 28, no. 1, p. 22-31. [CrossRef]

BRUNNER, A.M.; YAKOVLEV, I.A. and STRAUSS, S.H. (2004). Validating internal controls for quantitative plant gene expression studies. BMC Plant Biology, vol. 4, no. 14. [CrossRef]

BUSTIN, S.A. (2002). Quantification of mRNA using real-time reverse transcription PCR (RT-PCR): Trends and problems. Journal of Molecular Endocrinology, vol. 29, no. 1, p. 23-39. [CrossRef]

BUSTIN, S.A.; BENES, V.; GARSON, J.A.; HELLEMANS, J.; HUGGETT, J.; KUBISTA, M.; MUELLER, R.; NOLAN, T.; PFAFFL, M.W.; SHIPLEY, G.L.; VANDESOMPELE, J. and WITTWER, C.T. (2009). The MIQE guidelines: Minimum Information for Publication of Quantitative Real-Time PCR Experiments. Clinical Chemistry, vol. 55, no. 4, p. 611-622. [CrossRef]

CRUZ, F.; KALAOUN, S.; NOBILE, P.; COLOMBO, C.; ALMEIDA, J.; BARROS, L.M.G.; ROMANO, E.; GROSSIDE-SÁ, M.F.; VASLIN, M. and ALVES-FERREIRA, M. (2009). Evaluation of coffee reference genes for relative expression studies by quantitative real-time RT-PCR. Molecular Breeding, vol. 23, no. 4, p. 607-616. [CrossRef] 
DHANARAJ, A.L.; SLOVIN, J.P. and ROWLAND, L.J. (2004). Analysis of gene expression associated with cold acclimation in blueberry floral buds using expressed sequence tags. Plant Science, vol. 166, no. 4, p. 863872. [CrossRef]

GINZINGER, D.G. (2002). Gene quantification using real-time quantitative PCR: An emerging technology hits the mainstream. Experimental Hematology, vol. 30, no. 6, p. 503-512. [CrossRef]

HIGUCHI, R.; FOCKLER, C.; DOLLINGER, G. and WATSON, R. (1993). Kinetic PCR analysis: Real-time monitoring of DNA amplification reactions. Nature Biotechnology, vol. 11, no. 9, p. 1026-1030. [CrossRef]

HOENEMANN, C.; RICHARDT, S.; KRÜGER, K.; ZIMMER, A.D.; HOHE, A. and RENSING, S.A. (2010). Large impact of the apoplast on somatic embryogenesis in Cyclamen persicum offers possibilities for improved developmental control in vitro. BMC Plant Biology, vol. 10, no. 77. [CrossRef]

HONG, S.Y.; SEO, P.J.; YANG, M.S.; XIANG, F. and PARK, C.M. (2008). Exploring valid reference genes for gene expression studies in Brachypodium distachyon by real-time PCR. BMC Plant Biology, vol. 8, no. 112. [CrossRef]

JAIN, M.; NIJHAWAN, A.; TYAGI, A.K. and KHURANA, J.P. (2006). Validation of housekeeping genes as internal control for studying gene expression in rice by quantitative real-time PCR. Biochemical and Biophysical Research Communications, vol. 345, no. 2, p. 646-651. [CrossRef]

KUIJK, E.W.; DU PUY, L.; VAN TOL, H.T.A.; HAAGSMAN, H.P.; COLENBRANDER, B. and ROELEN, B.A.J. (2007). Validation of reference genes for quantitative RT-PCR studies in porcine oocytes and preimplantation embryos. BMC Developmental Biology, vol. 7, no. 58. [CrossRef]

LEE, J.M.; ROCHE, J.R.; DONAGHY, D.J.; THRUSH, A. and SATHISH, P. (2010). Validation of reference genes for quantitative RT-PCR studies of gene expression in perennial ryegrass (Lolium perenne L.). BMC Molecular Biology, vol. 11, no. 8. [CrossRef]

LIVAK, K.J. and SCHMITTGEN, T.D. (2001). Analysis of relative gene expression data using real-time quantitative PCR and the $2^{-\triangle \Delta C T}$ method. Methods, vol. 25, no. 4, p. 402-408. [CrossRef]

LYNGVED, R.; RENAUT, J.; HAUSMAN, J.F.; IVERSEN, T.H. and HVOSLEF-EIDE, A.K. (2008). Embryo-specific proteins in Cyclamen persicum analyzed with 2-D DIGE. Journal of Plant Growth Regulation, vol. 27, no. 4, p. 353-369. [CrossRef]

MAROUFI, A.; VAN BOCKSTAELE, E. and DE LOOSE, M. (2010). Validation of reference genes for gene expression analysis in chicory (Cichorium intybus) using quantitative real-time PCR. BMC Molecular Biology, vol. 11, no. 15. [CrossRef]

MORRISON, T.B.; WEIS, J.J. and WITTWER, C.T. (1998). Quantification of low-copy transcripts by continuous SYBR Green I monitoring during amplification. BioTechniques, vol. 24, no. 6, p. 954-962.

PFAFFL, M.W. (2004). Quantification strategies in real-time PCR. In: BUSTIN, S.A. ed. A-Z of quantitative PCR. La Jolla, CA, International University Line, p. 87-112.

PFAFFL, M.W.; TICHOPAD, A.; PRGOMET, C. and NEUVIANS, T.P. (2004). Determination of stable housekeeping genes, differentially regulated target genes and sample integrity: BestKeeper - Excel-based tool using pairwise correlations. Biotechnology Letters, vol. 26, no. 6, p. 509-515. [CrossRef]

RENSING, S.A.; LANG, D.; SCHUMANN, E.; RESKI, R. and HOHE, A. (2005). EST sequencing from embryogenic Cyclamen persicum cell cultures identifies a high proportion of transcripts homologous to plant genes involved in somatic embryogenesis. Journal of Plant Growth Regulation, vol. 24, no. 2, p. 102-115. [CrossRef]

RIRIE, K.M.; RASMUSSEN, R.P. and WITTWER, C.T. (1997). Product differentiation by analysis of DNA melting curves during the polymerase chain reaction. Analytical Biochemistry, vol. 245, no. 2, p. 154-160. [CrossRef]

ROZEN, S. and SKALETSKY, H. (2000). Primer3 on the WWW for general users and for biologist programmers. In: KRAWETZ, S. and MISENER, S. eds. Bioinformatics Methods and Protocols: Methods in Molecular Biology. Totowa, NJ, Humana Press, p. 365-386.

SCHWENKEL, H.G. and WINKELMANN, T. (1998). Plant regeneration via somatic embryogenesis from ovules of Cyclamen persicum Mill. Plant Tissue Culture and Biotechnology, vol. 4, p. 28-34.

SEYRING, M. and HOHE, A. (2005). Induction of desiccation-tolerance in somatic embryos of Cyclamen persicum Mill. The Journal of Horticultural Science \& Biotechnology, vol. 80, no. 1, p. 65-69.

SILVEIRA, É.D.; ALVES-FERREIRA, M.; GUIMARÃES, L.A.; DA SILVA, F.R. and CARNEIRO, V.T.C. (2009). Selection of reference genes for quantitative real-time PCR expression studies in the apomictic and sexual grass Brachiaria brizantha. BMC Plant Biology, vol. 9, no. 84. [CrossRef]

TONG, Z.; GAO, Z.; WANG, F.; ZHOU, J. and ZHANG, Z. (2009). Selection of reliable reference genes for gene expression studies in peach using real-time PCR. BMC Molecular Biology, vol. 10, no. 71. [CrossRef]

VANDESOMPELE, J.; DE PRETER, K.; PATTYN, F.; POPPE, B.; VAN ROY, N.; DE PAEPE, A. and SPELEMAN, F. (2002). Accurate normalization of real-time quantitative RT-PCR data by geometric averaging of multiple internal control genes. Genome Biology, vol. 3, no. 7. [CrossRef]

WINKELMANN, T.; HOHE, A. and SCHWENKEL, H.G. (1998). Establishing embryogenic suspension cultures in Cyclamen persicum 'Purple Flamed'. Advances in Horticultural Sciences, vol. 12, p. 25-30.

WINKELMANN, T.; HEINTZ, D.; VAN DORSSELAER, A.; SEREK, M. and BRAUN, H.-P. (2006). Proteomic analyses of somatic and zygotic embryos of Cyclamen persicum Mill. reveal new insights into seed and germination physiology. Planta, vol. 224, no. 3, p. 508-519. [CrossRef] 


\section{How to cite this article:}

HOENEMANN, C. and HOHE, A. (2011). Selection of reference genes for normalization of quantitative realtime PCR in cell cultures of Cyclamen persicum. Electronic Journal of Biotechnology, vol. 14, no. 1. http://dx.doi.org/10.2225/vol14-issue1-fulltext-8 